\title{
PENINGKATAN KETERAMPILAN KOLABORASI DESAIN MENGGUNAKAN MODEL KOOPERATIF TIPE STAD SECARA ONLINE
}

\author{
Sistina Angga Reni, Henry Praherdiono, Yerry Soepriyanto \\ Jurusan Teknologi Pendidikan, Fakultas Ilmu Pendidikan, Universitas Negeri Malang \\ Jalan Semarang 5 Malang 65145 0341-574700 \\ Email: sistinaanggareni@gmail.com
}

Article History

Received: 01 Oktober 2020, Accepted: 20 Februari 2021, Published: 10 Agustus 2021

\begin{abstract}
Abstrak
Penelitian ini memiliki untuk mengetahui adanya pengaruh penerapan model kooperatif tipe STAD terhadap peningkatan keterampilan kolaborasi desain mahasiswa antara sebelum dan sesudah pembelajaran. Penelitian ini memakai pre-experimental design. Sampel pada penelitian ini yaitu mahasiswa teknologi pendidikan angkatan 2017 offering B yang mengikuti mata kuliah Manajemen Sistem Informasi sebanyak 30 orang. Metode pengumpulan data yang digunakan adalah metode non-tes. Instrumen penelitian memakai angket peerassessment untuk mengukur keterampilan kolaborasi desain. Desain dalam hal ini adalah desain poster. Penelitian ini memakai uji Paired Sample T-Test dan uji N-Gain. Berdasarkan hasil pengolahan data uji Paired Sample T-Test didapatkan nilai sig (2-tailed) sebesar $0,000<0,05$, sehingga hipotesis h0 ditolak dan ha diterima. Hal tersebut menunjukkan mean sesudah perlakuan lebih tinggi dari mean sebelum perlakuan. Berdasarkan hasil analisia data dapat ditarik kesimpulan yaitu terdapat peningkatan keterampilan kolaborasi desain mahasiswa memakai model Kooperatif tipe STAD secara online. Hasil penelitian bisa difungsikan sebagai rekomendasi pemilihan model pembelajaran bagi pengajar.
\end{abstract}

Keyword: Model Pembelajaran, Kooperatif, STAD, Kolaborasi, Desain, Online

\begin{abstract}
This study has to determine the effect of the application of the cooperative model type STAD on improving student design collaboration skills between before and after learning. This study used a pre-experimental design. The sample in this study was 30 students of educational technology class 2017 offering $B$ who took Information Systems Management courses. The data collection method used is the non-test method. The research instrument used a peer-assessment questionnaire to measure design collaboration skills. The design in this case is the poster design. This study used the Paired Sample T-Test and the N-Gain test. Based on the results of the Paired Sample T-Test data processing, the sig (2-tailed) value is $0.000<0.05$, so the hypothesis h0 is rejected and ha is accepted. This shows that the mean after treatment is higher than the mean before treatment. Based on the results of data analysis, it can be concluded that there is an increase in student design collaboration skills using the STAD cooperative model online. The results of the research can be used as recommendations for selecting learning models for teachers.
\end{abstract}

Keyword: Learning Model, Cooperative, STAD, Collaboration, Design, Online 


\section{PENDAHULUAN}

Pendidikan di masa sekarang tidak hanya sebatas berorientasi pada nilai ujian semata namun perlu juga memperhatikan berbagai penguasaan keterampilan yang disesuaikan dengan banyaknya berbagai tuntutan kebutuhan abad 21. Menurut (Zubaidah, 2016) kehidupan abad 21 ini menuntut beragam keterampilan dimana harus benar-benar dikuasai masing-masing individu, karenanya besar harapan pendidikan di masa sekarang dapat menyiapkan pebelajar agar memiliki beragam keterampilan agar supaya menjadi individu yang berhasil. US-based Partnership for 21st Century Skills (P21), menuliskan keterampilan yangmana wajib untuk dikuasai pada abad-21 diantaranya "The 4Cs"communication, collaboration, critical thinking, and creativity. Hal tersebut tentunya dapat pula menjadi suatu perhatian pendidikan masa kini dalam rangka mempersiapkan pebelajar agar menguasai serta memiliki berbagai kompetensi dan kapabilitas.

Keterampilan kolaborasi adalah satu diantara beberapa skill yang relatif masih kurang dikuasai di Indonesia. Hal tersebut selaras dengan hasil study (Asia, 2010) pada Indonesia Skills Report memaparkan data pada modul karyawan (the employee module) pada bahasan keterampilan komunikasi serta keterampilan tim (kolaborasi) merupakan keterampilan paling utama dan paling dibutuhkan pada dunia kerja, namun keterampilan tersebut relatif masih cukup rendah di Indonesia.

Hal tersebut perlu menjadi catatan tersendiri bagi penyelenggaraan pendidikan di negara Indonesia. Peningkatan kualitas pendidikan dipengaruhi juga oleh keberhasilan selama dalam pelaksaan pembelajaran. Keterampilan dalam bekerjasama merupakan kunci dalam mewujudkan proses pembelajaran secara efektif, dan tentunya keterampilan ini dibutuhkan dalam lingkungan pekerjaan (Saenab et al., 2019). Menurut (Widodo et al., 2019) seberapa cerdas pebelajar tersebut namun jika tidak menguasai \& memiliki keterampilan kolaborasi secara baik, biasanya mahasiswa tersebut tetap kesulitan dalam mengemukakan gagasan kepada anggota timnya, sehingga pada akhirnya sulit untuk bekerjasama dalam bekerja.

Pada era sekarang, satu aktivitas yang sering dikerjakan secara berkolaborasi adalah desain. Berdasarkan perspektif desain, konsep desain yang kompleks dan rumit biasanya membutuhkan pengetahuan lebihdari satu orang. Tentunya dibutuhkan beragam pengetahuan dimana harus disesuaikan dengan kebutuhan desain yng diciptakan agar saling melengkapi sehingga mendapatkan satu hasil desain terbaik yang disepakati bersama. Menurut (Ulfiyati \& Utomo, 2015) berdasarkan kutipan hasil kajian pustaka dilakukannya, pendekatan tersebut dapat dilaksanakan selama proses desain untuk menyajikan hasil terbaik adalah kolaborasi desain.

Menurut (Chiu, 2002), kolaborasi desain yaitu sebuah kegiatan yangmana memerlukan partisipasi dari individu dalam rangka memperoleh bermacam-macam informasi serta mengorganisir tugas serta sumberdaya yang telah tersedia. Tujuan kolaborasi desain menurut (Hakiki \& Utomo, 2013) yaitu untuk berbagi pengalaman, ide, sumberdaya dan tanggung jawab. Menurut (Nandiroh et al., 2007) kolaborasi desain juga biasanya dapat diterapkan di setiap tahap-tahap pengembangan sebuah produk dimana memiliki tahap perencanaan serta tahap desain. Pada kesempatan kali ini, kegiatan kolaborasi dimulai dari tahapan perencanaan sampai pada tahapan desain. Produk desain yang dikembangkan pada penugusan ini yakni adalah media dua dimensi berupa poster.

Metode yang ditempuh untuk bisa mengetahui keterampilan kolaborasi desain mahasiswa layaknya penilaian keterampilan kolaborasi seperti umumnya yaitu dengan memberikan penugasan dimana memiliki unsur seperti proses menetapkan tujuan, membuat rencana, memilih strategi, mencoba solusi, dan merevisi rencana (Saenab et al., 2019). Cara tersebut dapat diwujudkan dengan cara menerapkan model dalam pembelajaran yang sesuai. (Primartadi, 2012). Memilih sebuah model pembelajaran dapat menjadi suatu hal krusial sebab kesuksesan proses pendidikan tidak sebatas ditentukan pula oleh pengajar dan siswa, tetapi adanya penerapan sebuah model pembelajaran yang sesuai. Satu diantara model pembelajaran yangmana menitikberatkan pada keterampilan kolaborasi 
adalah model pembelajaran kooperatif. (Solihatin, 2007) menyebutkan dengan adanya penerapan cooperatif learning, berlangsungnya proses pemahman serta penerimaan pebelajar akan dapat menjadikan lebih cepat \& mudah untuk memproses materi. Hal tersebut menerangkan kesuksesan dari belajar tidak hanya sekedar berdasarkan keterampilan individu saja namun ditentukan juga oleh kegiatan selama belajar dalam setiap kelompok belajar nila terlaksana dengan baik.

Model Kooperatif memiliki beberapa tipe. Satu diantara tipe yang dikenal mayoritas pendidik yakni tipe STAD. Menurut (Slavin, 2010) menyebutkan model kooperatif tipe STAD yakni satu diantara beragam tipe model kooperatif yangmana menitikberatkan pada interaksi di antara pebelajar agar saling menolong dan memberikan motivasi dalam penguasaan materi serta pencapaian prestasi belajar yang optimal. Model STAD dapat dikatakan metode yang paling sederhana. Model STAD cocok jika diterapkannya terutama oleh pengajar yang masih baru dan belum pernah menerapkan pendekatan kooperatif.

(Slavin, 2010) menyebutkan model tersebut adalah suatu bentuk penyelenggaraan pembelajaran yangmana dapat meningkatkan kualitas dari pembelajaran dikarenakan adanya alasan berikut. Alasan pertama yaitu beberapa penelitian sejenis sebelumnya ditemukan fakta diterapkannya model STAD secara efektif mampu menciptakan peningkatan nilai siswa serta menambah keterampilan interaksi sosial, tumbuhnya penerimaan kekurangan diri serdiri serta orang lain, mencukupi kebutuhan pebelajar untuk belajar, berfikir, keterampilan memecahkan permasalahan masalah serta menghubungkan prestasi belajar berupa pengetahuan dengan keterampilan. (Darmawan \& Dewanto, 2018) Model STAD memiliki tujuan utamanya untuk meminimalisasi pengajaran individual yang terbukti kurang efektif, selain juga ditunjukan untuk peningkatan pengetahuannya, meningkatnya keterampilan, serta motivasi pebelajar melalui belajar kelompok

Menurut (Trinovia \& Mulyanratna, 2013) menyebutkan model STAD dapat menciptakan peningkatkan motivasi pebelajar didalam kegiatan proses belajarnya. Peningkatan motivasi tersebut diharapkan sejalan beriringan dengan semangat pebelajar dalam berkolaborasi. Selanjutnya menurut (Slavin, 2010) sintaks model STAD tersusun atas lima hal yaitu presentasi dalam kelas, kerja kelompok, kuis, skor perkembangan individu, serta penghargaan untuk kelompok.

Pada masa ini menurut (Praherdhiono \& Adi, 2017) bahwa lingkungan belajar telah bergeser pada lingkungan online. Terlebih lagi akibat adanya virus COVID 19 membuat kegiatan proses pembelajarannya tidak memungkinkan untuk dilaksanakan dalam ruang kelas seperti biasanya. Hal tersebut menyebabkan seluruh kegiatan proses belajar diselenggarakan secara online. Menurut (Astini, 2020) terkait perubahan paradigma pembelajaran tersebut, mahasiswa banyak mengeluh, sebagai bukti ketidaksiapan mahasiswa secara internal yang berhubungan dengan nilai, sikap, pengetahuan, serta keterampilan, mengevaluasi, dan mengorganisasikan informasi.

Tidak dapat dipungikiri dalam pelaksanaan proses belajar melalui daring tentunya menghadapi berbagai tantangan dan peluang. Menurut (Setyosari, 2007) pembelajaran dilaksanakan secara daring memiliki potensi-potensi, antara lain: belajar dengan penuh makna, kemudahan dalam mengakses, dan meningkatnya nilai belajarnya. Satu diantara variasi proses kegiatan proses pembelajaran dimana dapat dilakukan dalam kurun waktu pandemik yakni penyelenggaraan pembelajaran melalui online. Selain penyampaian materi, menurut (Pujiasih, 2020) pembelajaran juga dapat dilakukan menggunakan pemberian penugasan (e-portofolio) dengan variasi kegiatan diantaranya dengan membuat sesuatu yangmana dapat dihasilkan secara visual berupa karya misalnya video, rekaman poster, foto serta peta konsep berdasarkan materinya. Pembeda penelitian ini dibandingkan penelitian lainnya yang sejenis yakni implementasi model kooperatif tipe STAD yang pelaksanaannya secara online. Sedangkan penelitian lain mayoritas dilaksanakan secara konvensional. 
Berdasarkan identifikasi masalah tersebut, maka implementasi model STAD secara online dapat dijadikan opsi model yangmana dapat dipergunakan dalam rangka peningkatan penguasaan keterampilan kolaborasi desain mahasiswa teknologi pendidikan.

\section{METODE}

Metode penelitian yang digunakan yaitu penelitian kuantitatif-eksperimen. Penelitian iini memiliki dua variabel. Model STAD berperan sebagai variabel bebas, sedangkan keterampilan kolaborasi desain sebagai variabel terikat. Model STAD dipilih sebagai variabel bebas karena model tersebut mempengaruhi keterampilan kolaborasi desain mahasiswa. Sedangkan untuk variabel terikatnya yakni keterampilan kolaborasi desain yang bisa diartikan sebagai penerapan keterampilan kolaborasi dalam bidang desain.

Desain peneltian yang digunakan yaitu desain pre-exsperimental design berupa One-Shot Case Study, yaitu dengan desain terdapat adanya satu kelompok belajar yang diberi treatment/perlakuan, dan selanjutnya diamati hasilnya (Sugiyono, 2010). Adapun rancangan desain One-Shot Case Study pada gambar 1, dengan keterangan $\mathrm{X}=$ Treatment yang diberikan (variabel independen), $\mathrm{O}=$ Observasi (Variabel dependen)

\begin{tabular}{|c|c|}
\hline $\mathrm{X}$ & $\mathrm{O}$ \\
\hline
\end{tabular}

Gambar 1. Pola Desain One-Shot Case Study

Populasi pada keterlaksaan penelitian ini meliputi seluruh mahasiswa Teknologi Pendidikan Fakultas Ilmu Pendidikan Universitas Negeri Malang angkatan 2017 yang mengikuti mata kuliah Manajemen Sistem Informasi berjumlah 105 mahasiswa yang terbagi dalam tiga offering. Sampel pada penelitian ini yaitu mahasiswa Teknologi Pendidikan Offering B angkatan 2017 yang keseluruhan berjumlah 30 mahasiswa.

Teknik pengumpulan datanya memakai metode non-tes. Instrumen penelitian yang dipakai didalam penelitian ini berbentuk angket peer-assessment. Angket peer-assessment tersebut memiliki fungsi khusus yang menjadi alat pengukuran keterampilan kolaborasi desain mahasiswa sebelum dan sesudah perlakuan. Butir-butir indikator penilaian yang terpadat di angket peer-assessment tersusun dari delapan item yang beracuan pada rubrik penilaian keterampilan kolaborasi desain. Pada tiap-tiap item terdapat empat kategori penilaian yang bisa diterjemahkan seperti berikut ini: skor 4 yang berarti sangat baik, skor 3 yang berarti baik, skor 2 yang berarti cukup, kemudian skor 1 yang berarti kurang. Setiap mahasiswa memberi penilaiannya untuk seluruh anggota kelompoknya. Selanjutnya angket tersebut yang sudah terisi, diolah datanya untuk memperoleh masing-masing skor kolaborasi desain setiap mahasiswa berdasarkan rata-rata penilaian yang dinilai dari tiap anggota kelompok masingmasing. Dengan demikian perolehan skor maksimalnya adalah 32.00.

Tahapan penelitian tersusun atas tiga tahap. Tahap pertama yaitu persiapan, meliputi membuat rubrik penilaiaan keterampilan kolaborasi desain, membuat instrumen angket, membuat Satuan Acara Perkuliahan (SAP), mengumpulkan media dan materi untuk disampaikan, menyusun soal kuis, dan membuat ruang belajar online pada edmodo. Selanjutnya tahap pelaksanaan, meliputi pembagian angket sebelum pembelajaran dimulai, pelaksanaan proses pembelajarannya berjalan mengikuti rancangan SAP dan disesuaikan sintaks model STAD yang menyampaikan materi tentang "Creating Creative Content", dan membagikan angket sesudah pembelajaran. Pengisian instrumen angket peerassessment sebelum pembelajaran bertujuan agar bisa mengetahui keadaan awal kelompok sebelum di berikan perlakuan. Kemudian setelah diberikan perlakuan, dilakukan pengisian instrumen angket peerassessment kembali agar mengetahui perubahan keadaan setiap kelompok. Pelaksanaan pembelajarannya dilaksanakan sebanyak satu kali pertemuan memakai edmodo. Terakhir tahap penyelesaian, meliputi mengolah dan menganalisa data yang didapatkan di hasil penelitian, 
menginterpretasikan hasil analisa yang kemudian digunakan membuat kesimpulan dari hasil hipotesis yang diujikan.

Hipotesis penelitian kali ini yaitu, Ho = tidak terdapat perbedaan rata-rata skor keterampilan kolaborasi desain mahasiswa sebelum dan sesudah memakai model STAD secara online, dan $\mathrm{Ha}=$ terdapat perbedaan rata-rata skor keterampilan kolaborasi desain mahasiswa sebelum dan sesudah memakai model pembelajaran kooperatif tipe STAD secara online. Seluruh proses analasi dana memakai SPSS 20.

Sebelum dilaksanakan uji hipotesis, perlu terlebih dulu dilaksanakan uji prasyarat yang meliputi pelaksanaan uji normalitas. Uji normalitas data dihitung memakai uji Kolmogorov-Smirnov. Dasar pengambilan keputusan yaitu memakai nilai signifikansi. Apabila nilai signifikansi pada hasil pengujian lebih besar dari alpha 0,05 maka data tersebut termasuk berdistribusi normal. Apabila hasil pengujian lebih kecil dari alpha 0,05 maka dapat dipastikan data tersebut termasuk tidak berdistribusi normal.

Pengujian hipotesis dputuskan berdasar pada hasil darii Uji Paired Sample T-Test dan bertujuan untuk membuktikan adanya perbedaan skor keterampilan kolaborasi desain mahasis sebelum dan sesudah adanya perlakuan. Kriteria pengambilan keputusan didasarkan pada nilai probabilitas untuk uji dua sisi yakni jika sig > 0,05 maka ho diterima, sedangkan jika sig < 0,05 maka Ho ditolak dan Ha diterima.

Selanjutnya dilakukan uji Normalized Gain atau N-Gain bertujuan untuk mengetahui efektivitas penggunaan suatu metode atau perlakuan tertentu dalam penelitian. Uji N-Gain dilakukan dengan cara menghitung selisih antara skor keterampilan kolaborasi desain sebelum dan sesudah perlakukan menggunakan model kooperatif tipe STAD. Nilai N-Gain dikategorikan menjadi tiga, yang dapat dilihat pada tabel 1 .

Tabel 1. Kategori Nilai N-Gain

\begin{tabular}{cc}
\hline Nilai $N$-Gain & Kategori \\
\hline $\mathrm{g}>0,7$ & Tinggi \\
\hline $0,3 \leq \mathrm{g} \leq 0,7$ & Sedang \\
\hline $\mathrm{g}<0,3$ & Rendah \\
\hline
\end{tabular}

\section{HASIL}

Hasil dari analisa deskriptif skor keterampilan kolaborasi desain mahasiswa sebelum dan sesudah perlakuan disajikan pada tabel 2 .

Tabel 2. Deskripsi Data Penelitian

\begin{tabular}{lccccc}
\hline & N & Minimum & Maximum & Mean & Std. Deviation \\
\hline PreEksperimen & 30 & 20,75 & 27,67 & 24,8327 & 1,61617 \\
\hline PostEksperimen & 30 & 24,00 & 30,75 & 27,2297 & 1,77859 \\
\hline Valid N (listwise) & 30 & & & & \\
\hline
\end{tabular}

Berdasarkan tabel 2 dapat diketahui sebelum memakai model STAD skor minimum sebesar 20,75 , sedangkan sesudah perlakukan sebesar 24,00. Selanjutnya skor maksimum yang didapatkan sebelum perlakuan yaitu 27,67, sedangkan sesudah perlakuan yaitu 30,75. Selanjutnya nilai means sebelum perlakukan sebesar 24,8327, sedangkan sesudah perlakukan sebesar 27,2297. 
Tabel 3. Tabel hasil uji normalitas

\begin{tabular}{llcccccc}
\hline \multirow{2}{*}{ Kelas } & \multicolumn{3}{c}{ Kolmogorov-Smirnov $^{\text {a }}$} & \multicolumn{3}{c}{ Shapiro-Wilk } \\
\cline { 2 - 8 } & & Statistic & Df & Sig. & Statistic & df & Sig. \\
\hline \multirow{2}{*}{ Skor } & PreEksperimen &, 103 & 30 &, $200^{*}$ &, 971 & 30 &, 560 \\
\cline { 2 - 8 } & PostEksperimen &, 132 & 30 &, 190 &, 973 & 30 &, 632 \\
\hline
\end{tabular}

Berdasarkan tabel 3, dari hasil pengujian asumsi normalitas menggunakan metode KolmogorovSmirnov dapat dijabarkan sebagai berikut :Pada kelas tersebut sebelum eksperimen mendapatkan nilai signifikansi sebesar 0,200 >0.05 sehingga dapat disimpulkan bahwa data tersebut bersifat normal. Sedangkan pada data sesudah eksperimen mendapatkan nilai signifikansi sebesar 0,190>0,05 sehingga dapat disimpulkan bahwa data tersebut bersifat normal. Sehingga secara keseluruhan data tersebut berdistribusi normal. Tabel 4 adalah tabel uji hipotesis memakai uji paired sample t-test.

Tabel 4. Hasil Uji Paired Sample T-Test

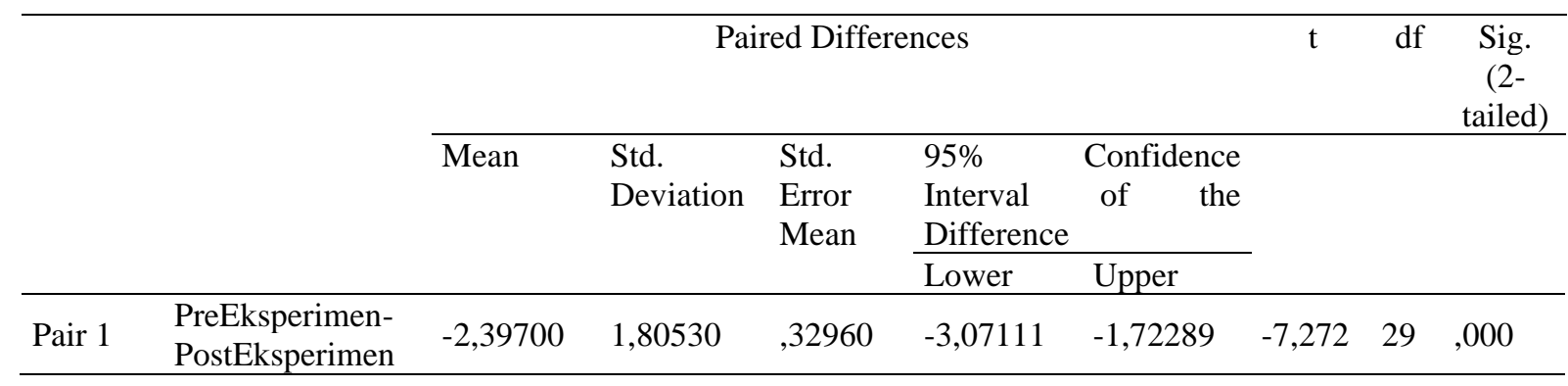

Berdasarkan sajian tabel diatas diperoleh nilai sig (2-tailed) sebesar 0,000. Mengacu pada ketentuan pengambilan keputusannya apabila nilai Sig. (2-tailed) lebih kecil 0,05 maka H0 ditolak dan Ha diterima. Berdasarkan hasil analisa tersebut maka dapat di simpulkan bahwa terdapat perbedaan rata-rata skor keterampilan kolaborasi desain mahasiswa sebelum dan sesudah memakai model pembelajaran kooperatif tipe STAD secara online. Tabel 5 berikut adalah tabel hasil uji N-Gain :

Tabel 5. Hasil uji N-Gain

\begin{tabular}{lllll}
\hline & \multicolumn{5}{c}{ Nilai N-Gain } \\
\hline g $<0,3$ & $0,3 \leq \mathrm{g} \leq 0,7$ & $\mathrm{~g}>0,7$ & Rata-rata \\
& Rendah & Tinggi & N-Gain \\
\hline Jumlah Siswa & 16 & 12 & 3 & 0,3255 \\
\hline
\end{tabular}

Berdasarkan uji N-Gain di atas dapat diketahui bahwa nilai N-Gain pada kategori rendah sebanyak 16, pada kategori sedang sebanyak 12 , dan pada kategori tinggi sebanyak 3 . Rata-rata Nilai N-Gain yaitu sebesar 0,3255. Kemudian didapatkan berdasarkan uji N-Gain bahwa efektivitas penggunaan model kooperatif tipe Student Team Achievement Division (STAD) terhadap keterampilan kolaborasi desain mahasiswa teknologi pendidikan pada kategori sedang.

\section{PEMBAHASAN}

Menurut (Sudarsana, 2018) kompetensi dalam kurikulum pendidikan meliputi pengetahuan kognitif, keterampilan serta nilai-nilai mendasar yang direfleksikan pada kebiasaan bertindak \& berpikir. Dengan adanya kebiasaan tersebut yang konsisten tentunya sangat memungkinkan pebelajar menjadi kompeten. Dalam konteks ini kompeten diartikan sebagai menguasai pengetahuan pada satu bidang tertentu, trampil serta dapat pula menerapkan kemampuan ilmu tersebut serta menunjukkannya melalui sikap yang positif. Keterampilan kolaborasi desain tentunya memang tidak memungkinkan diajarkan secara langsung dalam tempo yang singkat namun perlu adanya proses pembiasaan. 
Penggunaan moodel ini pada pembelajarannya merupakan satu langkah awal untuk membentuk kebiasaan tersebut.

Menurut (Haris, 2016) penggunaannya model kooperatif tipe STAD menggunakan konsepkonsep penghargaan bagi tim, tanggung jawab individu, dan kesempatan sukses yangmana sama ternyata memberikan efek positif. Bagian paling mendasar dari model STAD yakni adanya kerjasama anggota dari kelompok dan kompetisi antar kelompok (Widiyarto, 2017). Pada Penggunaan model pembelajaran STAD guru mengutamakan adanya kerjasama antar pebelajar dalam kelompok untuk mencapai tujuan pembelajaran di dalam kelas.

Kemudian kelebihan dari model ini mengutip dari (Laa et al., 2017) yakni dapat melatih pebelajar dalam bidang pengembangan kecakapan di bidang sosial dan kecakapan kognitif. Selain itu, dengan terlaksananya pembelajaran student centered maka mahasiswa yang secara individual atau berkempok memiliki kesempatan untuk menuangkan idenya dan bisa mengaplikasikannya pada saat menyelesaikan penugasan. Penugasan sebaiknya dikaitkan sesuai pada dunia nyata. Menurut (Khan \& Inamullah, 2011) diantara metode-metode pembelajaran kooperatif yang lain, STAD mudah dilaksanakan oleh pembelajar serta dapat difungsikan mengajar untuk beragam materi pelajaran dari tingkat dasar hingga universitas.

Penelitian ini menggunakan penilaian antar teman (peer-assessment) pada aspek keterampilan kolaborasi desain. Menurut (Muslich, 2014) model penilaian ini dianggap mempunyai kekuatan dalam pembentukkan karakter pribadi yang positif selain pebelajar mempunyai kompetensi pengetahuan tetapi juga ketrampilan. Masih menurut (Muslich, 2014) penilaian antar teman dapat digunakan untuk mengukur kemampuan diri siswa dan kemampuan antar teman pada aspek sikap, pengetahuan, dan ketrampilan. Selanjutnya menurut hasil penelitian (Wijayanti, 2017) Peer-assessment dapat diterapakan dalam semua bidang pembelajaran dan akan memberikan sumbangan terhadap pemahaman konsep di dalamnya.

Gambaran umum pelaksanaan pembelajaran selama diskusi kelompok sangat wajar terjadi perbedaan pendapat, hal ini dapat memneri pengaruh yang positif bagi pebelajar. Karena dengan demikian mereka harus menyamakan tujuan dan persepsinya sesuai kemampuan masing-masing sehingga mereka mendapatkan pemahaman konsep yang lebih baik. Apabila pebelajar menemui masalah dalam pembelajaran, mereka berusaha menyelesaikan masalah tersebut dengan saling bertukar pikiran dalam kelompok.

Penerapan model pembelajaran kooperatif tipe STAD dapat meningkatkan keterampilan kolaborasi desain karena pada dasarnya dalam pembelajaran secara berkelompok akan menimbulkan keaktifan pebelajar baik kognitif, afektif, maupun psikomotorik. Hal tersebut tentunya akan menumbuhkan kerjasama, sikap saling memberi dan menerima, serta tumbuhnya semangat dan keberanian sehingga pebelajar termotivasi untuk terus belajar dan berusaha. Dalam proses diskusi dan kerja kelompok, peneliti berperan sebagai fasilitator sehingga membuat proses berpikir pebelajar lebih optimal serta menumbuhkan motivasi pebelajar karena merasa senang dan mengalami sendiri belajar mengajar dengan teman-teman sebayanya.

Berdasarkan analisis data dari hasil penelitian, telah diperoleh bahwa $\mathrm{H} 1$ diterima dan $\mathrm{H} 0$ ditolak. Hal ini berarti terdapat pengaruh model pembelajaran kooperatif tipe STAD secara online terhadap keterampilan kolaborasi desain Mahasiswa Teknologi Pendidikan. Perbedaan skor rata-rata meningkat sebesar 2.397 dari nilai sebelum perlakuan sebesar 24,8327 menjadi 27,2297 sesudah perlakuan. Skor tersebut merupakan nilai dari angket peer-assessment dimana dapat menunjukkan keterampilan kolaborasi desain mahasiswa yang diukur berdasarkan rubrik penilaian. Besarnya perbedaan rata-rata bernilai positif yaitu sebesar 2,397 yang artinya rata-rata skor kolaborasi desain mahasiswa sesudah perlakuan lebih besar dari rata-rata sebelum perlakuan. Selanjutnya hasil uji N-Gain rata-ratanya yaitu 
sebesar 0,3255. Sehingga dapat disimpulkan bahwa efektivitas penggunaan model kooperatif tipe Student Team Achievement Division (STAD) terhadap keterampilan kolaborasi desain mahasiswa teknologi pendidikan pada kategori sedang. Selain itu sebuah penemuan menarik pada penelitian ini adalah keterampilan kolaborasi desain pada mahasiswa meningkat jika dinilai menggunakan peerassessment, bukan oleh pengajar.

Hasil penelitian yang menunjukkan terdapat pengaruh dari penggunaann model kooperatif tipe STAD secara online terhadap peningkatan keterampilan kolaboborasi desain mahasiswa teknologi pendidikan sejalan dengan penelitian sebelumnya yang dilakukan oleh Suryo Widodo, Jatmiko, Ika Santia, Yuni Katmaningsih yang mengangkat judul Pemberdayaan Keterampilan kolaborasi Mahasiswa Menggunakan Model Pembelajaran Student Team Achievement Division. Berdasarkan hasil penelitian tersebut dapat ditarik kesimpulan bahwa penerapan model pembelajaran STAD dapat meningkatkan keterampilan kolaborasi mahasiswa sebesar 4,50\%.

Adanya pengaruh yang positif dan signifikan antara pembelajaran kooperatif tipe STAD terhadap keterampilan kolaborasi desain dikarenakan pada pembelajaran dengan model tersebut dilakukan dengan beberapa tahapan pembelajaran yaitu salah satunya adalah penempatan mahasiswa belajar dalam kelompok. Menurut penelitian (Puspawati et al., 2013) adanya pengaruh pemilihan model STAD pada hasil prestasi belajar tidak terlepas dari hakikat model pembelajaran ini dimana tidak saja menekankan unsur kerjasama tetapi di dalamnya juga ada unsur kompetisi baik secara individual maupun secara kelompok. Temuan tersebut senada dengan beberapa penelitian sebelumnya.

Penelitian yang dilakukan (Karim et al., 2012) didapatkan hasil keterampilan kerjasama siswa mengalami peningkatan yang signifikan setelah diterapkan model kooperatif tipe STAD mengalami peningkatan untuk setiap aspek pada tiap-tiap pertemuannya dengan rincian tiap aspek berikut ini: kegiatan mengambil giliran dan berbagi tugas sebesar 91\%, berada di kelompok sebesar 83\%, mendorong partisipasi sebesar 64\%, mendengarkan sebesar $85 \%$, mengungkapkan ketidaksetujuan memakai cara-cara yangmana bisa diterima sebesar $66 \%$, dan bertanya sebesar $73 \%$. Selanjutnya penelitian oleh (Wati, 2016) Pembelajaran kooperatif tipe STAD pada perubahan benda disekitar kita mampu menciptakan adanya peningkatan prestasi belajar serta kerjasama siswa. Temuan ini dapat diamati dari peningkatan prestasi belajar pebelajarnya disetiap siklusnya. Sebelum penelitian ketuntasan belajar klasikal 40\%, pelaksanaan siklus I terjadi peningkatan sehingga presentasenya menjadi $71 \%$ kemudian didalam pelaksanaan siklus II meningkat sehingga menjad $87 \%$. Model kooperatif STAD dapat memicu peningkatan kerjasama siswa hingga $74 \%$.

Terakhir, penelitian lain yang sesuai dilakukan oleh (Lailatul, 2019) tentang Penerapan STAD (Student Team Achievement Division) Berbantuan Mind Mapping untuk Meningkatkan Keterampilan kolaborasi dan Hasil Belajar Siswa Kelas XI IPA 1 SMA Negeri 7 Malang. Hasil penelitian tersebut menunjukkan bahwa penerapan STAD berbantuan mind mapping dapat meningkatkan keterampilan kolaborasi siswa sebesar 15\%. Hal tersebut juga sesuai dengan kelebihan model pembelajaran kooperatif tipe STAD, salah satunya adalah pembelajaran dilakukan secara berkelompok dimana peningkatan interaksi antar anggota kelompok sejalan dengan peningkatan keterampilan kolaborasi. Penelitian yang dikerjakan oleh (Lailatul, 2019) menunjukkan tindakan memakai model STAD menggunakan bantuan mind mapping bias menimbulkan peningkatan keterampilan kolaborasi dan hasil dari belajar siswanya.

\section{SIMPULAN}

Pelaksanaan proses pembelajaran dengan cara online memakai model STAD terbukti cukup efektuf untuk bisa dipakai menjadi suatu upaya peningkatan keterampilan kolaborasi desain. Desain yang dikerjakan selama proses pembelajaran disini yang dimaksud berupa desain poster yang berisikan konten tentang pendidikan. Kesimpulan berdasarkan hasil analisis data sera dari hasil uji hipotesis yaitu terdapat peningkatan keterampilan kolaborasi desain sesudah kegiatan pembelajaran memakai 
model koperatif tipe STAD. Setelah kegiatan proses pembelajaran memakai model STAD secara online didapatkan hasil rata-rata skor dari angket peer-assessment meningkat sebesar 2.397.

Berdasarkan hasil penelitian, terdapat beberapa saran bagi calon pengajar agar dapat menerapkan model STAD sebagai solusi untuk melatih kemampuan kolaborasi desain sejak dini. Terlebih pada saat ini pembelajaran mayoritas dilaksanakan secara online. Selanjutnya saran untuk pebelajar agar tidak sekedar belajar berfokus pada materi saja. Penting juga melatih kemampuan kolaborasi khususnya kolaborasi desain. Sedangkan untuk penelitian selanjutnya, penerapan model STAD baiknya dilakukan lebih dari satu pertemuan untuk mengukur hasil keterampilan kolaborasi desain dengan lebih baik. Mengingat penelitian ini jauh dari sempurna, hendaknya penelitian selanjutnya agar lebih diperinci lagi indikator-indikator untuk mengukur dengan akurat seberapa kemampuan kolaborasi desain tiap pebelajar agar cukup merepresentasikan kemampuan kolaborasi masing-masing mahasiswa.

\section{DAFTAR RUJUKAN}

Asia, E. (2010). INDONESIA SKILLS REPORT.

Astini, N. K. S. (2020). Tantangan Dan Peluang Pemanfaatan Teknologi Informasi Dalam Pembelajaran Online Masa Covid-19. Cetta: Jurnal Ilmu Pendidikan, 3(2), 241-255.

Chiu, M.-L. (2002). An organizational view of design communication in design collaboration. Design Studies, 23(2), 187-210.

Darmawan, R., \& Dewanto, D. (2018). Penerapan kurikulum 2013 untuk meningkatkan kemampuan kolaborasi, hasil belajar dan respon siswa kelas X TKR 1 pada mata pelajaran pekerjaan dasar teknik otomotif di SMKN 1 Kalianget. Jurnal Pendidikan Teknik Mesin, 6(03), 53-58.

Hakiki, M. S., \& Utomo, C. (2013). Faktor Kritis Penentu Keberhasilan Kolaborasi Desain Pada Perusahaan Properti Di Jawa Timur. Surabaya, Indonesia, Program Studi MMT-ITS.

HARIS, I. N. (2016). Pengaruh model pembelajaran kooperatif tipe STAD terhadap sikap tanggung jawab. Biormatika: Jurnal Ilmiah Fakultas Keguruan Dan Ilmu Pendidikan, 2(01).

Karim, S., Utami, S., \& Utami, F. R. (2012). Penerapan Model Pembelajaran Kooperatif Tipe Stad (Student-Teams-Achievment-Divisions) Untuk Meningkatkan Prestasi Belajar Dan Kerjasama Siswa. Jurnal Pengajaran MIPA, 17(2), 245-250.

Khan, G. N., \& Inamullah, H. M. (2011). Effect of student's team achievement division (STAD) on academic achievement of students. Asian Social Science, 7(12), 211-215.

Laa, N., Winata, H., \& Meilani, R. I. (2017). Pengaruh model pembelajaran kooperatif tipe student teams achievement division terhadap minat belajar siswa. Jurnal Pendidikan Manajemen Perkantoran (JPManper), 2(2), 251-260.

Lailatul, I. (2019). Penerapan STAD (Student Team Achievement Division) Berbantuan Mind Mapping untuk Meningkatkan Kemampuan Kolaborasi dan Hasil Belajar Siswa Kelas XI IPA 1 SMA Negeri 7 Malang. SKRIPSI Jurusan Biologi-Fakultas MIPA UM.

Muslich, K. M. (2014). Pengembangan Model Assessment Afektif Berbasis Self Assessment dan Peer Assessment di SMA Negeri 1. Jurnal Kebijakan Dan Pengembangan Pendidikan, 2(2).

Nandiroh, S., Fitriadi, R., \& Hikmawati, H. (2007). PENGEMBANGAN KOLABORASI DESAIN CASING PRODUK FLASH DISK BERBASIS WEB YANG MENDUKUNG KARAKTERISTIK KOLABORASI. Jurnal Ilmiah Teknik Industri, 6(1), 48-57.

Praherdhiono, H., \& Adi, E. P. (2017). Constructing Learning Results as Learning Object Through Open Learning System. 3rd International Conference on Education and Training (ICET 2017), 295-300.

Primartadi, A. (2012). Pengaruh metode student teams-achievement division (STAD) dan problem based learning terhadap hasil belajar ditinjau dari potensi akademik siswa SMK otomotif. Jurnal Pendidikan Vokasi, 2(2). 
Pujiasih, E. (2020). MEMBANGUN GENERASI EMAS DENGAN VARIASI PEMBELAJARAN ONLINE DI MASA PANDEMI COVID-19. Ideguru: Jurnal Karya Ilmiah Guru, 5(1), 42-48.

Puspawati, N., Lasmawan, W., \& Dantes, N. (2013). Pengaruh Model Pembelajaran Kooperatif Tipe STAD Terhadap Minat dan Prestasi Belajar IPS pada Siswa Kelas IV Sekolah Dasar Nomor 3 Legian-Badung. Ganesha University of Education.

Saenab, S., Yunus, S. R., \& Husain, H. (2019). Pengaruh Penggunaan Model Project Based Learning Terhadap Keterampilan Kolaborasi Mahasiswa Pendidikan IPA. BIOSEL (Biology Science and Education): Jurnal Penelitian Science Dan Pendidikan, 8(1), $29-41$.

Setyosari, P. (2007). Pembelajaran Sistem Online: Tantangan dan Rangsangan. Majalah Ilmiah Pembelajaran, 2, 1-10.

Slavin, E. R. (2010). Cooperative Learning Teori, Riset dan Praktik, dalam Coopertive Learning: Theori, Reearch and Practice, terj. Nurulita Nasron, Cet. VII. Bandung: Nusa Media.

Solihatin, E. (2007). Cooperative Learning analisis model pembelajaran IPS. Jakarta: Bumi Aksara.

Sudarsana, I. K. (2018). Pengaruh model pembelajaran kooperatif terhadap peningkatan mutu hasil belajar siswa. Jurnal Penjaminan Mutu, 4(1), 20-31.

Sugiyono, D. (2010). Metode penelitian kuantitatif dan R\&D. Bandung: Alfabeta.

Trinovia, V., \& Mulyanratna, M. (2013). Penerapan Strategi Index Card Match (Mencari Pasangan Kartu) dalam Model Pembelajaran Kooperatif Tipe STAD pada Materi Alat Optik. Inovasi Pendidikan Fisika, 2(3).

Ulfiyati, Y., \& Utomo, C. (2015). Model Teoritis Pengaruh Gaya Kepemimpinan dan Manajemen Pengetahuan pada Keberhasilan Kolaborasi Desain. Jurnal Teknik ITS, 4(1), D82-D85.

Wati, I. (2016). Peningkatan Kerjasama pada Materi Perubahan Benda Menggunakan Model Pembelajaran Cooperative Tipe STAD. Jurnal Penelitian Pendidikan Indonesia, 1(1).

Widiyarto, S. (2017). Pengaruh Metode Student Teams Achievement Division (STAD) dan Pemahaman Struktur Kalimat terhadap Keterampilan Menulis Narasi. Lectura: Jurnal Pendidikan, 8(1).

Widodo, S., Jatmiko, J., Santia, I., \& Katminingsih, Y. (2019). Pemberdayaan kemampuan kolaborasi mahasiswa menggunakan model pembelajaran student teams achievement division. Jurnal Math Educator Nusantara: Wahana Publikasi Karya Tulis Ilmiah Di Bidang Pendidikan Matematika, 5(2), 182-189.

Wijayanti, A. (2017). Efektivitas Self Assessment dan Peer Assessment dalam Pembentukan Karakter Siswa. Ann,(Southern Illinois University Press, USA, 1984), 267, 268.

Zubaidah, S. (2016). Keterampilan abad ke-21: Keterampilan yang diajarkan melalui pembelajaran. Seminar Nasional Pendidikan Dengan Tema "isu-Isu Strategis Pembelajaran MIPA Abad, 21(10). 